\title{
Effects of temperature on consolidation and consistency of clayey soils
}

\author{
Atsushi Ogawa ${ }^{1, *}$, Atsushi Takai $^{2}$, Takumi Shimizu ${ }^{2}$ and Takeshi Katsumi ${ }^{2}$ \\ ${ }^{1}$ Okumura Corporation, Environmental Technology Office, Osaka, Japan \\ ${ }^{2}$ Kyoto University, Graduate School of Global Environmental Studies, Kyoto, Japan
}

\begin{abstract}
This study focuses on the effects of temperature on the consolidation property and consistency of clay for thermal improvement of soft clay ground. Although it is already known that an increase in temperature can accelerate consolidation of clay, the degree of the temperature effect has not yet been generalized between various clays. In this study, a series of one-dimensional consolidation tests at different temperatures $(17,23$, 35,50 , and $65^{\circ} \mathrm{C}$ ) using 2 processed clays and 3 natural clayey soils dredged at ports are presented. To evaluate the temperature effect on soil consistency, which might affect the consolidation behavior, atterberg limits of the clays were also evaluated at different temperatures. As a result, it was confirmed that, although the temperature effect on consistency limits varies depending on the type of clay, the consolidation coefficient increases with increase in temperature in all the clay soils tested.
\end{abstract}

\section{Introduction}

In recent years, it has been pointed out that the ground temperature in urban areas has been rising due to the effects of global warming, the exhaustion of heat from underground structures, and the introduction of underground heat pump systems. Until now, in Japan, it has been said that the temperature in the ground at a depth deeper than $10 \mathrm{~m}$ is stable at around $15^{\circ} \mathrm{C}$ to $20^{\circ} \mathrm{C}$ throughout the year. For this reason, the effects of underground temperature changes on the ground have not been fully studied. However, if the utilization of geothermal heat, which is a renewable energy, is promoted toward the realization of a decarbonized society, it is expected that the temperature change in the ground will become more remarkable. Therefore, it is increasingly important to understand the ground behavior with respect to temperature changes.

It has long been known that the physical, chemical and biological properties of the ground are affected by changes in temperature. Among them, in the consolidation of clay, the following items can be affected; the volume of soil particles and pore water, the viscosity of pore water, the interface between the soil particle surface and pore water change due to temperature change, and consolidation settlement amount and consolidation rate $[1,2,3,4]$. In addition, a ground improvement method that accelerates the consolidation of soft clay ground using the temperature effect has been proposed. $[5,6]$ However, the heating of the ground requires a large amount of energy, so that it has not been put to practical use yet. In order to develop a consolidation acceleration method using the temperature effect, it is necessary to evaluate the temperature dependency of consolidation,
Different soils are expected to be quantitatively characterized by different consolidation and consistency parameters. If the temperature dependence of consolidation can be generalized, it can be used not only for the consolidation acceleration method but also for ground deformation prediction during underground heat storage, which is very important for promoting the use of geothermal heat. In this study, the temperature dependence of soil consistency and consolidation was confirmed by performing laboratory experiments at various temperatures using various types of clay, and the relationship between the two was evaluated.

\section{Methodologies}

\subsection{Materials}

The specimens used were kaolinite clay (ASP200, BASF Corporation), Kasaoka clay (Tachibana Material Co., Ltd.), which are commercially available industrial plasticines, and Osaka Bay clay, Moji Port clay, Tokuyama Port clay, which are sediments dredged from ports and harbors. Table 1 gives a summary of the basic properties of each specimen. Because of the limited amount of material, Moji Port clay were not subjected to some tests. Liquid limits and activities differ greatly between industrial clay and dredged clay at room temperature conditions $\left(23^{\circ} \mathrm{C}\right)$. Kasaoka clay, Moji Port clay and Tokuyama Port clay contain swellable smectite, and Kasaoka clay showed the highest smectite content of $36 \%$. The smectite content of Kaolinite clay was lower than the lower limit of quantification. Fig. 1 shows the particle size distribution of each material. Kaolinite clay

\footnotetext{
* Corresponding author: atsushi.ogawa@okumuragumi.jp
} 
Table 1. Basic properties of the materials used.

\begin{tabular}{|c|c|c|c|c|c|c|c|c|c|}
\hline & \multicolumn{4}{|c|}{ Industrial plasticines } & \multicolumn{5}{|c|}{ Sediments dredged from ports and harbors } \\
\hline & \multicolumn{2}{|c|}{ Kaolinite clay } & \multicolumn{2}{|c|}{ Kasaoka clay } & \multicolumn{2}{|c|}{ Osaka Bay clay } & Moji Port clay & \multicolumn{2}{|c|}{ Tokuyama Port clay } \\
\hline Particle density $\left(\mathrm{g} / \mathrm{cm}^{3}\right)$ & \multicolumn{2}{|c|}{2.601} & \multicolumn{2}{|c|}{2.675} & \multicolumn{2}{|c|}{2.621} & 2.641 & \multicolumn{2}{|c|}{2.580} \\
\hline Plastic limit (PL) (\%) & \multicolumn{2}{|c|}{30.2} & \multicolumn{2}{|c|}{24.6} & \multicolumn{2}{|c|}{39.2} & 32.4 & \multicolumn{2}{|c|}{37.0} \\
\hline Liquid limit (LL) (\%) & \multicolumn{2}{|c|}{77.0} & \multicolumn{2}{|c|}{58.5} & \multicolumn{2}{|c|}{101.2} & 120.9 & \multicolumn{2}{|c|}{120.8} \\
\hline Plastic index (PI) & \multicolumn{2}{|c|}{46.8} & \multicolumn{2}{|c|}{33.9} & \multicolumn{2}{|c|}{63.0} & 88.5 & \multicolumn{2}{|c|}{83.8} \\
\hline Content finer than $2 \mu \mathrm{m}(\%)$ & \multicolumn{2}{|c|}{92.4} & \multicolumn{2}{|c|}{43.1} & \multicolumn{2}{|c|}{57.0} & 54.5 & \multicolumn{2}{|c|}{50.3} \\
\hline Activity & \multicolumn{2}{|c|}{0.51} & \multicolumn{2}{|c|}{0.79} & \multicolumn{2}{|c|}{1.11} & 1.62 & \multicolumn{2}{|c|}{1.67} \\
\hline Loss on ignition (\%) & \multicolumn{2}{|c|}{12.1} & \multicolumn{2}{|c|}{2.7} & \multicolumn{2}{|c|}{8.2} & - & \multicolumn{2}{|c|}{8.6} \\
\hline Smectite content $(\%)$ & \multicolumn{2}{|c|}{$<3.0$} & \multicolumn{2}{|c|}{36.0} & \multicolumn{2}{|c|}{9.4} & - & \multicolumn{2}{|c|}{15.0} \\
\hline Major minerals & $\mathrm{SiO}_{2}$ & $46.6 \%$ & $\mathrm{SiO}_{2}$ & $66.2 \%$ & $\mathrm{SiO}_{2}$ & $58.2 \%$ & & $\mathrm{SiO}_{2}$ & $58.5 \%$ \\
\hline & $\mathrm{Al}_{2} \mathrm{O}_{3}$ & $38.3 \%$ & $\mathrm{Al}_{2} \mathrm{O}_{3}$ & $19.3 \%$ & $\mathrm{Al}_{2} \mathrm{O}_{3}$ & $14.5 \%$ & - & $\mathrm{Al}_{2} \mathrm{O}_{3}$ & $16.3 \%$ \\
\hline & Others & $15.1 \%$ & Others & $14.5 \%$ & Others & $27.3 \%$ & & Others & $25.2 \%$ \\
\hline
\end{tabular}

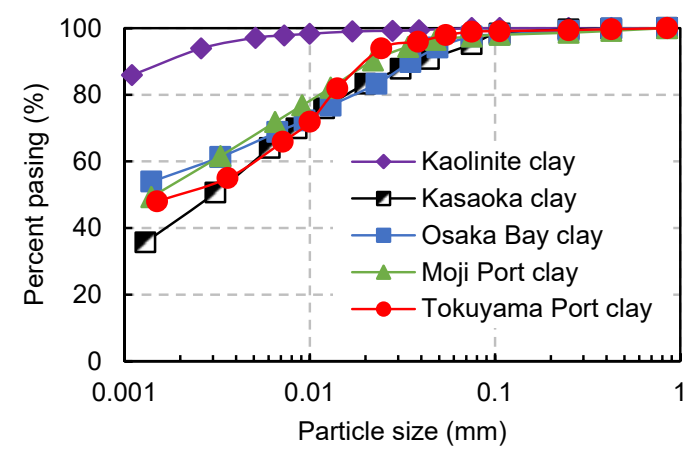

Fig. 1. Particle size of used materials.

has the highest content of clay finer than $2 \mu \mathrm{m}$. The other clays showed similar particle size distributions.

\subsection{Atterberg limit test}

Liquid limit and plastic limit were determined according to JIS A 1205:2009 in a constant temperature chamber. During the test, the chamber set to the specified temperatures $\left(10^{\circ} \mathrm{C}, 23^{\circ} \mathrm{C}, 35^{\circ} \mathrm{C}\right.$, and $\left.50^{\circ} \mathrm{C}\right)$. The materials for the test were allowed to stand for more than 12 hours inside a constant temperature chamber adjusted to the test temperature. At the beginning of and during the test, the thermometer was checked to confirm that the specimen remained at the predetermined temperature. When changing the water content, distilled water adjusted to the same temperature as the test temperature was added for wetting, and a blower was used for drying.

\subsection{One-dimensional consolidation test}

The consolidation tests were performed in accordance to JGS A 1217:2009, using the apparatus shown in Fig. 2. The water content of each specimen was adjusted to 1.1 times the liquid limit of each clay material because typical dredged clays show 1.1 times their liquid limit in Japan. The materials were filled in a cylindrical consolidation cell having diameter of $10 \mathrm{~cm}$ and height of $5 \mathrm{~cm}$. The consolidation cell was struck lightly on the side with a hammer after filling to increase density. All these specimens were prepared at room temperature of $23^{\circ} \mathrm{C}$. Table 2 gives the wet densities, degrees of saturation and initial void ratio of the specimens at the beginning of the test. Loading was applied with a Bellofram cylinder; consolidation pressures from 4.9 to $628 \mathrm{kPa}$ were applied, with the load doubling at each step. The loading time was 24 hours at each step. Specimen temperature was

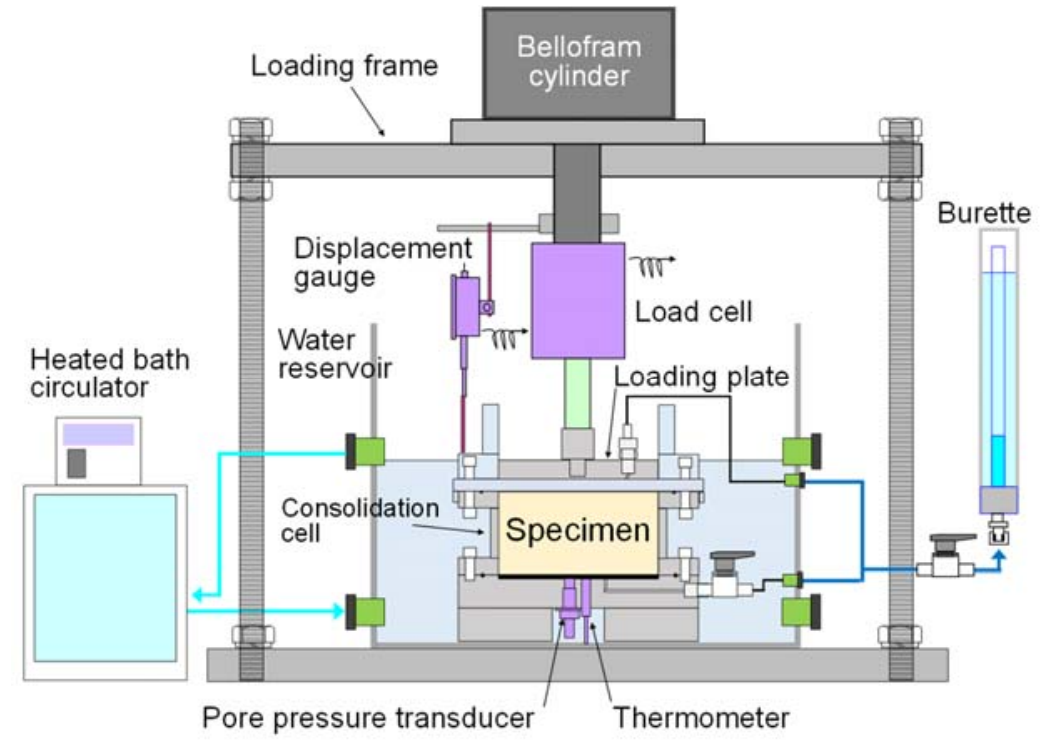

Fig. 2. Apparatus for the one-dimensional consolidation test. 
controlled by immersing the cylindrical cell in a bath connected with a heated bath circulator. The tests for each specimen were performed at constant temperatures of 17 , 23, 35, 50, and $65^{\circ} \mathrm{C}$. However, Moji Port clay was tested in the range of $17{ }^{\circ} \mathrm{C}$ to $50{ }^{\circ} \mathrm{C}$. At the beginning of and during the test, the thermometer installed at the bottom of the cell was checked to confirm that the specimens remained at the predetermined temperature.

Table 2. Initial conditions of the test.

\begin{tabular}{lccc}
\hline & $\begin{array}{c}\text { Wet density } \\
\left(\mathrm{g} / \mathrm{cm}^{3}\right)\end{array}$ & $\begin{array}{c}\text { Degree of } \\
\text { saturation }(\%)\end{array}$ & $\begin{array}{c}\text { Initial } \\
\text { void ratio }\end{array}$ \\
\hline Kaolinite clay & 1.44 & 94.4 & 2.38 \\
Kasaoka clay & 1.55 & 94.2 & 1.86 \\
Osaka Bay clay & 1.39 & 99.1 & 3.10 \\
Moji Port clay & 1.35 & 99.6 & 3.64 \\
Tokuyama Port clay & 1.35 & 99.7 & 3.51 \\
\hline
\end{tabular}

\section{Consistency limits}

Figure 3 shows the relationship between the temperature and the liquid limit, plastic limit. For industrial plasticines, the liquid limit is generally unaffected by temperature, tending to remain constant throughout the temperature range tested. In contrast, for Tokuyama Port clay and Osaka Bay clay, which are natural clays, the liquid limit trends lower with the increase in temperature. We found no significant changes in plastic limits with changes in temperature for any of the clays, a finding consistent with the results of existing studies. The results of the test showed that changes in temperature affected liquid limits only for Tokuyama Port clay and Osaka Bay clay. If the decrease in the liquid limit of clay is attributable to reduced pore water viscosity induced by higher temperature, we would expect increasing the temperature to reduce the liquid limits of all the clays. Furthermore, since the effect of temperature change on the volume of soil particles and pore water should be similar for any soils, the factors resulting in the change in liquid limits for Tokuyama Port clay and Osaka Bay with
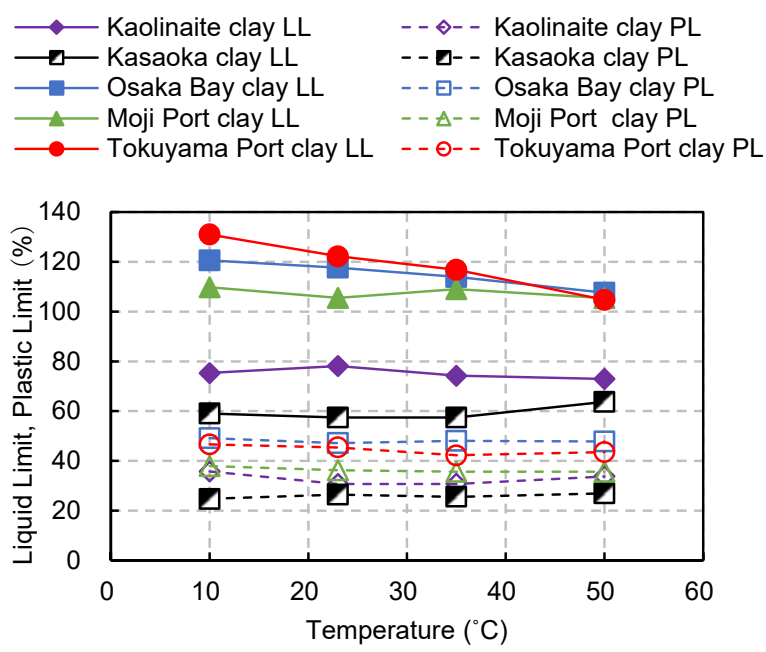

Fig. 3. Relationship between consistency limit and temperature. changes in temperature are believed to be the changes in interfacial effects between pore water and soil particles. These changes may be caused by temperature change, dissolution of substances into the pore water, and/or precipitation of components dissolved in pore water.

\section{Consolidation properties}

\subsection{Compressibility and temperature}

Figure 4 shows the change in the amount of settlement over time. Among the industrial plasticines, the higher the temperature, the greater the settlement in kaolin clay, but the opposite tendency in Kasaoka clay. The difference in the amount of settlement that occurs with each temperature is small in the initial loading stage, but it becomes noticeable from the third stage to the fifth stage, and then decreases again after that. In the natural clay, although the difference in the amount of settlement was observed depending on the test temperature, the regularity like natural clay could not be confirmed.

Figure 5 shows the relationship between coefficient of volume compressibility and consolidation pressure at each test temperature. For all clays, the coefficient of volume compressibility decreased with increasing consolidation pressure. Further, when the consolidation pressure was the same, there was no difference in the coefficient of volume compressibility due to the difference in the test temperature. The industrial plasticines and the natural clay showed the same tendency, and especially when the consolidation pressure was $10 \mathrm{kPa}$ or more, the coefficient of volume compressibility of all the clays were almost the same. Therefore, it can be seen that the volumetric compression coefficient has no temperature dependency or material dependency, and simply depends on the consolidation pressure.

\subsection{Consolidation rate and temperature}

Figure 6 shows the relationship between the consolidation pressure and the consolidation coefficient of each clay. Comparing the natural clay and the industrial plasticines, the consolidation coefficient of the natural clay was larger under the same consolidation pressure. Except for Kasaoka Clay, the coefficient of consolidation tended to increase with increasing consolidation pressure after the second stage loading. This is because the structure of soil particles tends to become denser as the loading pressure increases, but in clayey soil with low permeability, the pressure immediately after loading acts on the pore water, and the pore water pressure increases, resulting in a hydraulic gradient. Is large. As a result, it is considered that the drainage of pore water was accelerated. The Kasaoka clay showed the same tendency as other clays up to an average consolidation pressure of $111 \mathrm{kPa}$, but the consolidation coefficient decreased when the pressure became higher than that. This is thought to be due to the swellable smectite contained in Kasaoka clay. The soil particles adsorb water molecules due to their surface charge, and this layer of adsorbed water is called an 

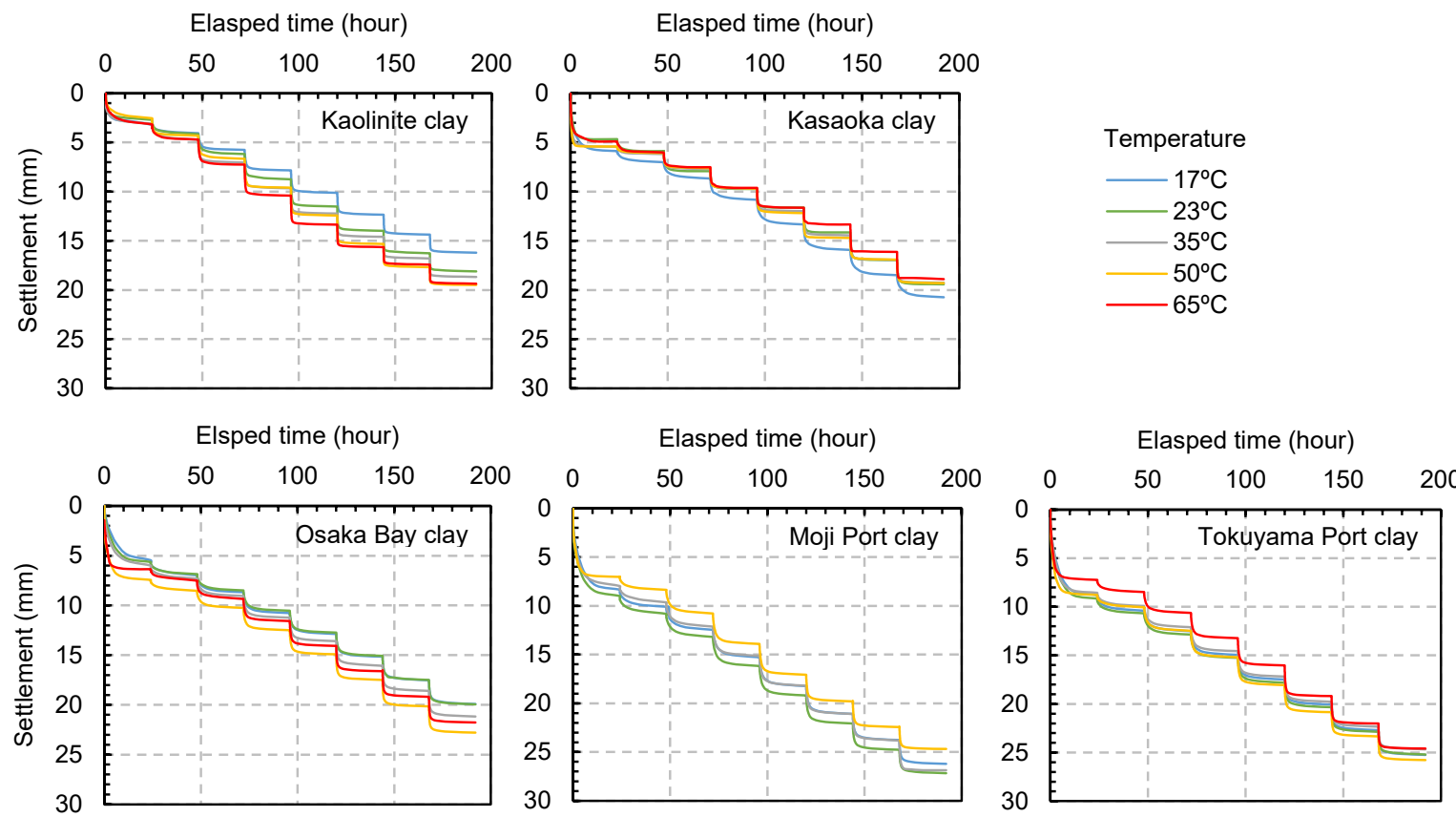

Fig. 4. Relationship between elasped time and settlement.

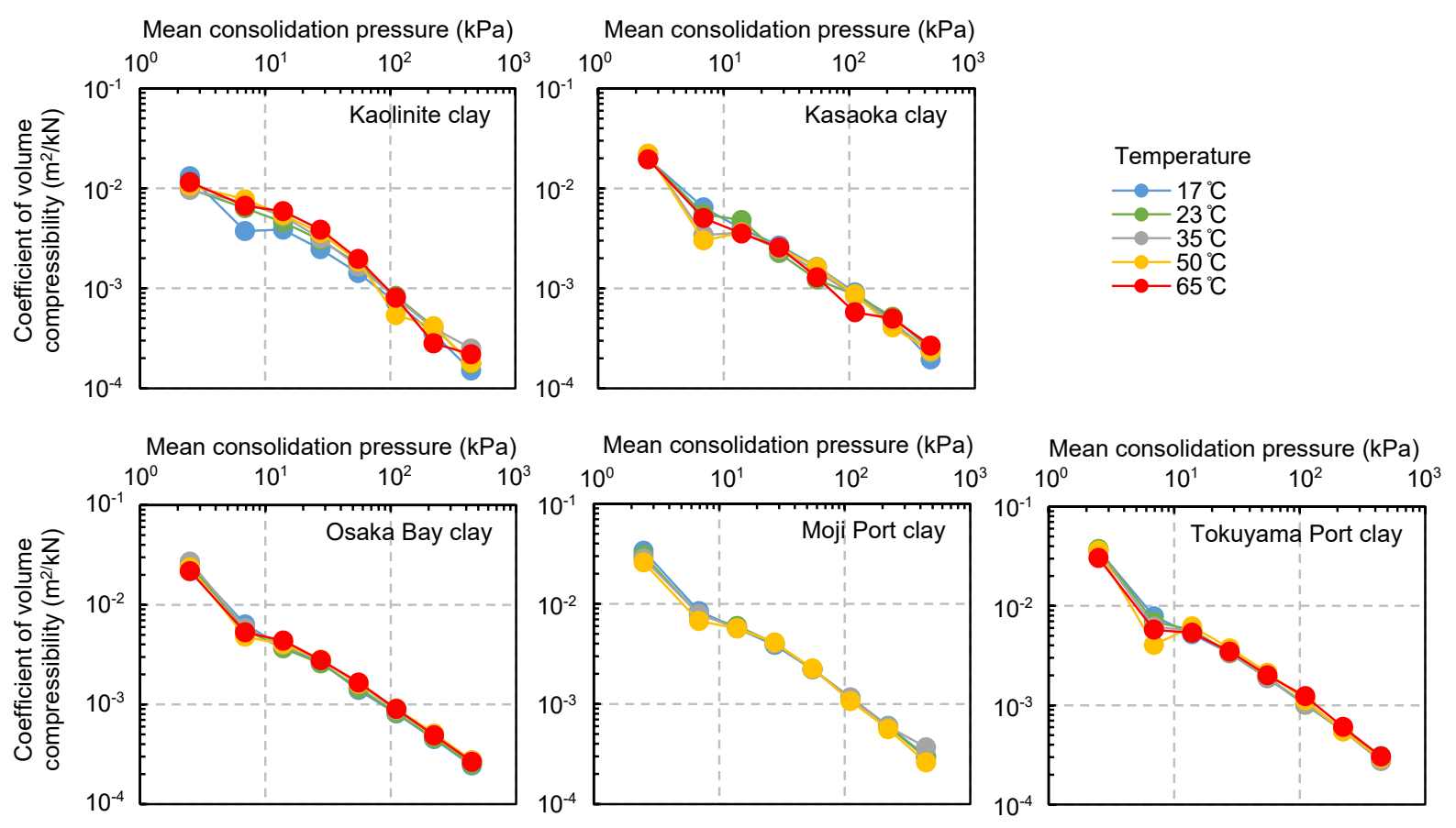

Fig. 5. Relationship between consolidation pressure and coefficient of volume compressicbility.

electric double layer and normally does not contribute to drainage of pore water. Compared with other clay minerals, smectite has a large specific surface area and a high surface charge, so that a thick electric double layer is formed. Therefore, it is speculated that when the consolidation pressure becomes large and the distance between the soil particles becomes short, the water permeability greatly decreases due to the influence of the electric double layer and the consolidation coefficient also decreases.

Figure 7 shows the relationship between the mean coefficient of consolidation and temperature. Here, the mean coefficient of consolidation refers to the mean value of the coefficient of consolidation obtained at each 

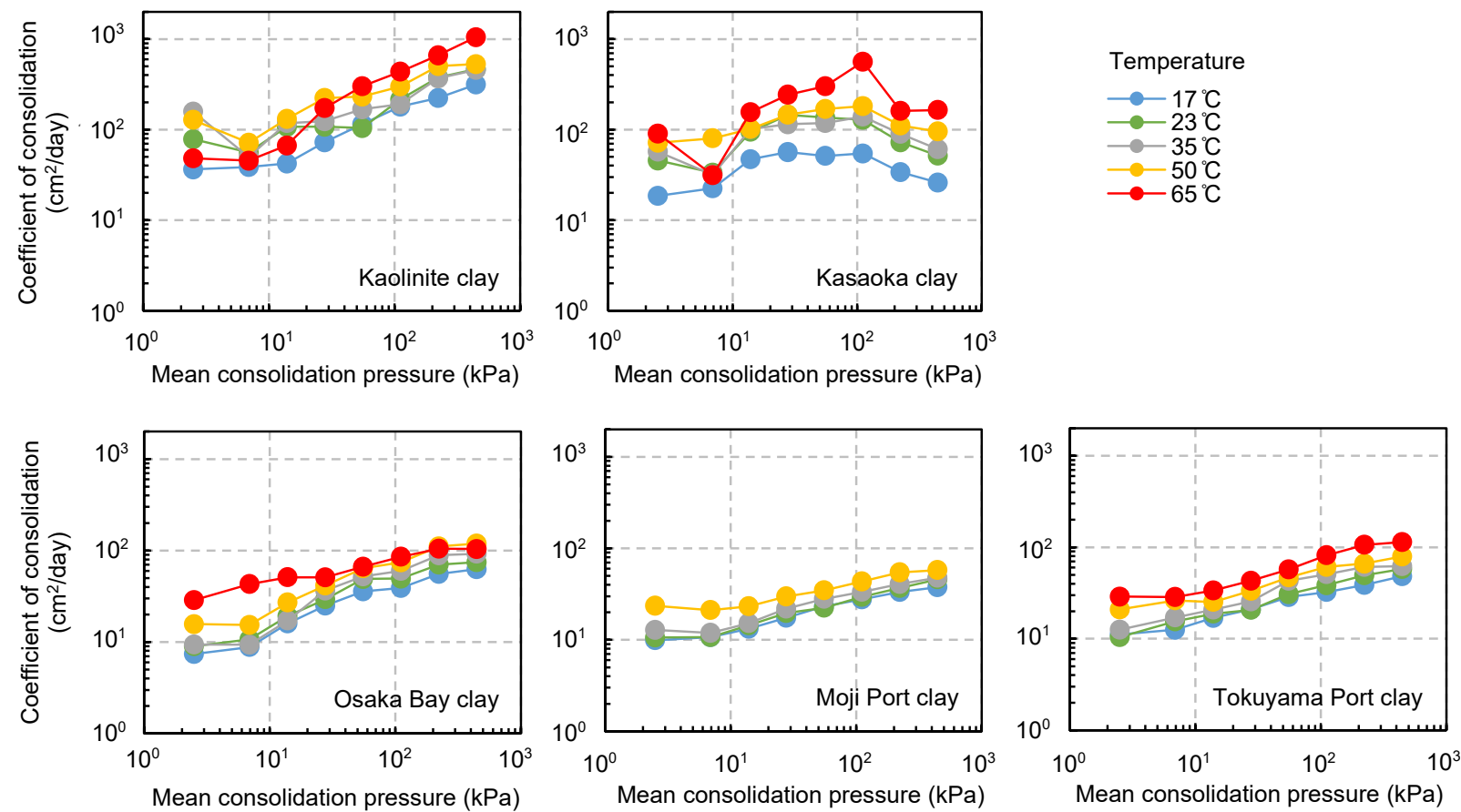

Fig. 6. Relationship between consolidation pressure and coefficient of consolidation.

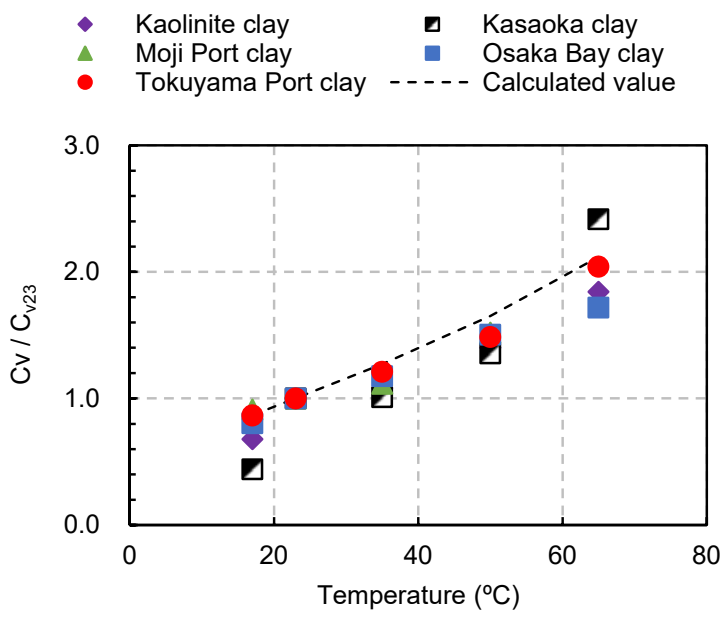

Fig. 7. Relationship between coefficient of consolidation and temperature.

loading step ( $4.9 \mathrm{kPa}-628 \mathrm{kPa})$ at each temperature. In all clays, the mean coefficient of consolidation increases with increasing temperature, confirming that the coefficient of consolidation increases with temperature regardless of clay type. We can express the coefficient of consolidation using the unit weight of water $\gamma_{\mathrm{w}}$, hydraulic conductivity $k$, and coefficient of volume compressibility $m_{\mathrm{v}}$ as follows.

$$
c_{\mathrm{v}}=\frac{k}{m_{\mathrm{v}} \gamma_{\mathrm{w}}}
$$

$\diamond$ Kaolinite clay $23^{\circ} \mathrm{C}$ - Kaolinite clay $50^{\circ} \mathrm{C}$ - Kasaoka clay $35^{\circ} \mathrm{C}$ 口Osaka Bay clay $23^{\circ} \mathrm{C}$ - Osaka Bay clay $50^{\circ} \mathrm{C}$ $\triangle$ Moji Port clay $35^{\circ} \mathrm{C}$ oTokuyama Port clay $23^{\circ} \mathrm{C}$

- Tokuyama Port clay $50^{\circ} \mathrm{C}$

$\diamond$ Kaolinite clay $35^{\circ} \mathrm{C}$ -Kasaoka clay $23^{\circ} \mathrm{C}$ $\square$ Kasaoka clay $50^{\circ} \mathrm{C}$ $\square$ Osaka Bay clay $35^{\circ} \mathrm{C}$

$\triangle$ Moji Port clay $23^{\circ} \mathrm{C}$

$\triangle$ Moji Port clay $50^{\circ} \mathrm{C}$

o Tokuyama Port clay $35^{\circ} \mathrm{C}$

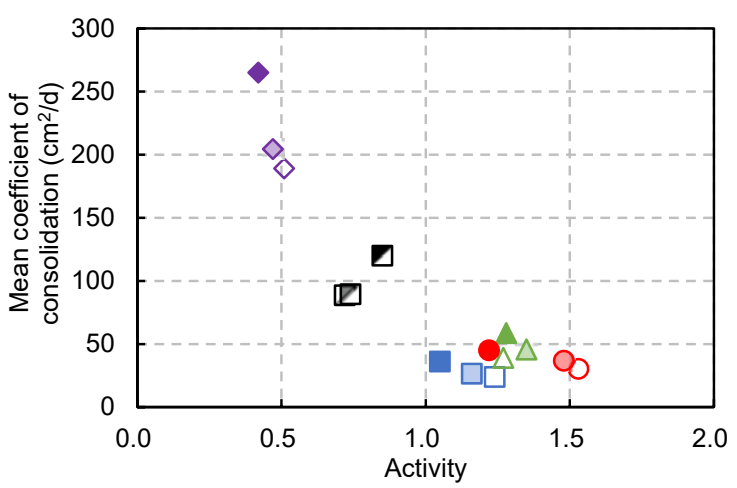

Fig. 8. Relationship between coefficient of consolidation and activity.

The viscosity of water at a given temperature can be calculated using the following empirical formula proposed by Hillel [7]:

$$
\eta_{T}=-0.00046575 \cdot \ln T+0.00239138
$$

where $\eta_{\mathrm{T}}$ is the viscosity of water at $T^{\circ} \mathrm{C}(\mathrm{Pa} \cdot \mathrm{s})$ and $T$ is temperature $\left({ }^{\circ} \mathrm{C}\right)$.

Since the temperature dependence of $m_{\mathrm{v}}$ was not confirmed as described in Section 4.1, the rate of change 
of the consolidation coefficient can be calculated from the rate of change of the viscosity of water and the rate of change of the unit volume weight using equation (1). Here, the coefficients for consolidation at $17^{\circ} \mathrm{C}, 35^{\circ} \mathrm{C}$, $50^{\circ} \mathrm{C}$, and $65^{\circ} \mathrm{C}$, respectively, can be calculated to 0.87 times, 1.27 times, 1.65 times, and 2.12 times that at $23^{\circ} \mathrm{C}$. As shown in Figure 7, the calculated and experimental results are in good agreement for all clays. This result supports that the coefficient of consolidation of water significantly influences the viscosiy and that the rate of consolidation will increase with decreasing pore water viscosity resulting from rising ground temperature.

\subsection{Consistency and coefficient of consolidation}

Figure 8, a plot of the results obtained in tests performed at $23^{\circ} \mathrm{C}, 35^{\circ} \mathrm{C}$, and $50^{\circ} \mathrm{C}$, illustrates the relationship between activity and coefficient of consolidation. The test confirmed a strong inverse correlation between coefficient of consolidation and activity. Activity is an index of physisorption and chemical affinity of clay, and is represented by the following equation (3) [8].

$$
A=\frac{I_{\mathrm{P}}}{F_{2 \mu \mathrm{m}}}
$$

where $A$ is activity of soil, $I_{\mathrm{P}}$ is plastic index and $F_{2 \mu \mathrm{m}}$ is weight percent finer than $2 \mu \mathrm{m}$.

This suggests that the interfacial effects between soil particles and pore water contribute to changes in the coefficient of consolidation. One example of interfacial effects between soil particles and pore water is the formation of the diffuse double layer, a layer of water formed by electrical adsorption of water onto soil particles. The thickness of this layer generally increases in proportion to the specific surface area and surface charge of soil particles, and the higher the activity of clay, the stronger the tendency. Therefore, it is speculated that as the activity increases, the effective voids that contribute to permeation decrease, limiting the movement of free water and decreasing the coefficient of consolidation.

\section{Conclusions}

In this study, in order to evaluate the effect of temperature on the consolidation characteristics of clays, atterberg limit tests and one-dimensional consolidation tests were conducted at temperatures varied from $17-65^{\circ} \mathrm{C}$ for industrial plasticines and sediments dredged from the seabed. The main achievements are as follows.

(1) For clays having pore water with high seawater content, such as sediment dredged from the seafloor, the coefficient of volume compressibility decreases with increasing temperature.

(2) The coefficient of consolidation increases with increasing temperature regardless of clay type. The magnitude of this increase is dominated by changes in the viscosiy of the pore water.

(3) The strong correlation discovered between activity and mean value of the coefficient of consolidation indicates that the rate of consolidation may be estimated based on activity, which can be determined through simple physical tests.

The authors would like to thank T. Hongo (Geo-Research Institute), H. Shiraishi and S. Hagiwara (Okumura Corporation) for their great support to the experiments in this manuscript.

\section{References}

1) H.M. Abuel-Naga, D.T. Bergado, A. Bouazza, G.V. Ramana, "Volume change behaviour of saturated clays under drained heating conditions: experimental results and constitutive modeling." Can Geotech J., 44(8), 942-956 (2007)

2) E.E. Mon, S. Hamamoto, K. Kawamoto, T. Komatsu, P. Moldrup, "Temperature effects on geotechnical properties of kaolin clay: simultaneous measurements of consolidation characteristics, shear stiffness, and permeability using a modified oedometer." GSTF Int. J. Geol. Sci., 1(1), 1-10 (2013)

3) I. Towhata, P. Kuntiwattanakul, I. Seko, K. Ohishi, "Volume change of clays induced by heating as observed in consolidation tests." Soils Found., 33(4), 170-183 (1993)

4) I. Towhata, P. Kuntiwattanakul, H. Kobayashi, “A preliminary study on heating of clays to examine possible effects of temperature on soil-mechanical properties.” Soils Found., 33(4),184-190, (1993)

5) K. Adachi, M. Murakami, "Consolidation mechanism of clayey ground under heated-drain consolidation." Proc. Jpn. Soc. Civ. Eng., 596, 39-48, (1998)

6) C.P. Pothiraksanon, D.T. Bergado, H.M. Abuel-Naga, "Full-scale embankment consolidation test using prefabricated vertical thermal drains." Soils Found., 50(5), 599-608, (2010)

7) D. Hillel, Fundamentals of Soil Physics, Academic Press, New York (1980)

8) A.W.Skempon, "The colloidal activity of clay." Proc. 3rd ICSMFE, I, 57-61 (1953) 